\title{
The Effects of Arsenic Trioxide in Combination with Retinoic Acids on Cutaneous T-Cell Lymphoma Cell Lines
}

\author{
Marc Beyer $^{a}$ Staffan Vandersee ${ }^{a, c}$ loana Cosagarea ${ }^{d}$ Rachid Touba $^{a}$ \\ Markus Möbs ${ }^{a, b}$ Chalid Assaf ${ }^{a, e}$
}

a Skin Cancer Centre Charité, Department of Dermatology and Allergy, and ' ${ }^{\mathrm{V}}$ Institute for Pathology, Charité Universitätsmedizin Berlin, Berlin, ' Department of Dermatology and Allergy, Central German Armed Forces Hospital, Koblenz, ${ }^{d}$ Klinik und Poliklinik für Dermatologie, Allergologie und Venerologie, Universitätsklinikum Essen, Essen, and e Department of Dermatology and Allergy, Helios Klinikum Krefeld, Krefeld, Germany

\section{Key Words}

Arsenic trioxide - Combination therapy · Sézary syndrome · Retinoids $\cdot$ All-trans-retinoic acid $\cdot$ Bexarotene $\cdot$ Cutaneous T-cell lymphoma $\cdot$ Mycosis fungoides

\begin{abstract}
Cutaneous T-cell lymphomas (CTCL) are characterized by an infiltration of the skin with malignant T cells. Curative treatments for aggressive entities such as Sézary syndrome have not been identified yet. Arsenic trioxide $\left(\mathrm{AsO}_{3}\right)$ is used for the treatment of acute promyelocytic leukemia in combination with retinoids. As the latter are established treatment options in $\mathrm{CTCL}$, we sought to evaluate the efficacy of $\mathrm{AsO}_{3}$ for mono- and combination therapy in vitro. Analyses for apoptosis, cell cycle inhibition, cytotoxicity and cell viability were made after incubation of CTCL cells with $\mathrm{AsO}_{3}$ alone or in combination with the retinoids all-trans-retinoic acid or bexarotene. While $\mathrm{AsO}_{3}$ induced apoptosis, retinoids did not at the time point of analysis. However, retinoids strongly reduced cell viability. Due to the efficient apoptosis induction, $\mathrm{AsO}_{3}$ might be a potentially suitable agent for CTCL treatment, although this effect was not increased by retinoids.
\end{abstract}

(c) 2016 S. Karger AG, Basel

\section{KARGER}

E-Mail karger@karger.com

www.karger.com/spp

\section{Introduction}

Sézary syndrome belongs to the group of primary cutaneous T-cell lymphoma (CTCL), characterized by a cutaneous infiltration as well as leukemic distribution of malignant T cells and a 5-year survival of only $24 \%[1,2]$. Even considering the overall scarcity of CTCL, it is a rare condition with a reported incidence of $0.1 / 1$ million person-years [3]. Despite many of the mechanisms leading to malignancy being still unclear, resistance to apoptosis seems to be one of the major features of disease propagation in CTCL [4]. In this context, overexpression of NF$\kappa \mathrm{B}, \mathrm{bcl}-2$, and c-FLIP among others is known to contribute to apoptosis resistance [5]. Furthermore, it has been shown that agents inducing apoptosis in CTCL cells often act via downregulation of these overexpressed antiapoptotic factors $[6,7]$. This is of interest, because the initial treatment of CTCL like mycosis fungoides and Sézary syndrome is preferably done with immunomodu-

Marc Beyer and Staffan Vandersee contributed equally as primary and Markus Möbs and Chalid Assaf as senior investigators. 
latory agents such as interferon- $\alpha$, photochemotherapy (PUVA), extracorporeal photopheresis or retinoids like bexarotene, the latter even being able to be delivered topically $[8,9]$. Although these therapies have proven efficacious, remissions in general are not long lasting. Cytoreductive therapies, despite also being effective, achieve neither long-lived remissions nor do they alter the course of disease when used early after diagnosis $[10,11]$. Furthermore, they impair the immune system that is already afflicted by the lymphoma itself. The severity of Sézary syndrome and a limited existing arsenal of treatment options underline the necessity for conducting research on novel therapeutical modalities. In this respect, arsenic trioxide $\left(\mathrm{AsO}_{3}\right)$ is a substance with known efficacy for the treatment of hematologic malignant diseases. Having been used since antiquity for a variety of ailments [12], $\mathrm{AsO}_{3}$ has been identified as the effective component of a traditional Chinese medicine in the treatment of acute promyelocytic leukemia (APL) and is nowadays approved for this disease [13]. Furthermore, antineoplastic effects were observed in a variety of tumor cell lines, mostly due to cell cycle arrest or direct induction of apoptosis [14-16]. Due to this, in particular two factors make this substance a promising agent for CTCL treatment: the first is the fact mentioned above, namely that the mode of action seems to rely on induction of apoptosis and among others downregulates bcl-2 that as stated comediates apoptotic resistance in CTCL [17]. Secondly $\mathrm{AsO}_{3}$ proved to be particularly effective in APL when being combined with the retinoid all-trans-retinoic acid (ATRA), achieving complete remissions in 11 of 12 patients in a pilot study [18]. Concerning CTCL, in vitro experiments have shown that $\mathrm{AsO}_{3}$ can induce apoptosis in CTCL cell lines. Furthermore, intratumoral injection of $\mathrm{AsO}_{3}$ led to complete remission in a mouse model of CTCL, and treatment of 2 CTCL patients with $\mathrm{AsO}_{3}$ led to stable disease in the one and partial remission in the other patient $[19,20]$. The finding of a favorable combination of $\mathrm{AsO}_{3}$ and retinoids in APL is especially interesting, as the latter represent a mainstay in CTCL treatment. They exert a multitude of effects in a variety of cells, affecting proliferation, differentiation, immune response and apoptosis and act by binding to specific nuclear receptors [21]. Two receptor classes are known, retinoid A receptor (RAR, comprised of three different known types), targeted among others by ATRA, and retinoid X receptor (RXR), the target of bexarotene. Studies indicate that in CTCL treatment, but of other malignancies such as melanoma cell lines as well, cell cycle inhibition seems to be the most important antineo- plastic effect of retinoids and to offer the possibility of increased efficacy when combined with $\mathrm{AsO}_{3}[22,23]$. These data represented the rationale for in vitro assessing the efficacy and mode of action of $\mathrm{AsO}_{3}$ alone and in combination with several established retinoids for the treatment of cutaneous lymphoma cell lines.

\section{Materials and Methods}

\section{Cell Lines and Culture Conditions}

The two CTCL cell lines SeAx [24] and Hut-78 [25], both established from patients with Sézary syndrome, were cultured at $37^{\circ} \mathrm{C}, 5 \% \mathrm{CO}_{2}$ in RPMI 1640 medium (Invitrogen/Life Technologies) supplemented with L-glutamine, fetal bovine serum, and antibiotics (100 units $/ \mathrm{ml}$ penicillin, $100 \mu \mathrm{g} / \mathrm{ml}$ streptomycin, all PAA, Austria). $\mathrm{AsO}_{3}$ (Sigma-Aldrich, Germany) stock solution was dissolved in $1 \mathrm{~mm} \mathrm{NaOH}$ at $30 \mu \mathrm{M}$ und diluted in cell culture medium for the final dose. ATRA (Sigma-Aldrich) and bexarotene (Calbiochem, USA) were dissolved in dimethylsulfoxide, ascorbic acid and $\mathrm{N}$-acetylcysteine in sterile water. For all experiments with single substances, cells were cultured in multiwell plates with the respective substance for 24-72 h. For combined treatment of cells with ascorbic acid and $\mathrm{N}$-acetylcysteine, cells were preincubated with the respective substance for $1 \mathrm{~h}$ before addition of $\mathrm{AsO}_{3}$. For combined treatment with retinoids, cells were preincubated with ATRA or bexarotene for $48 \mathrm{~h}$ and then treated with $\mathrm{AsO}_{3}$ for $24 \mathrm{~h}$. The respective solvents were used as controls.

\section{Cell Cycle Analysis and Detection of Apoptosis}

Cells were harvested by centrifugation, washed once with cold phosphate-buffered saline, fixed with prechilled $70 \%$ ethanol at $-20^{\circ} \mathrm{C}$ for $24 \mathrm{~h}$, and stained for $30 \mathrm{~min}$ with phosphate-buffered saline containing $0.1 \%$ sodium citrate, $20 \mu \mathrm{g} / \mathrm{ml}$ propidium iodide, $0.2 \mathrm{mg} / \mathrm{ml}$ RNase A and $0.1 \%$ Triton X-100. Cells were then analyzed on a flow FACSCalibur flow cytometer (BD Bioscience) using CellQuest Pro (BD Bioscience), WinMDI 2.9 (Scripps Research Institute, La Jolla, Calif., USA).

\section{Cytotoxicity Assay}

Cytotoxicity was determined by measuring the amount of lactate dehydrogenase (LDH) in the cell culture supernatant using the Cytotoxicity Detection Kit from Roche Diagnostics according to the recommendations of the manufacturer.

\section{Apoptosis Detection by DNA Fragmentation ELISA}

Apoptosis was measured by detection of DNA fragmentation using the Cell Death Detection Kit (Roche Diagnostics) according to the manufacturer's recommendations. Optical density values were normalized by division through the optical density of LDH activity (Cytotoxicity Detection Kit, Roche; see above) of the cell lysate to compensate for different amounts of lysed cells.

\section{Cell Viability Assay}

Cell viability was analyzed with the cell proliferation reagent WST-1 (water-soluble tetrazolium; Roche), as recommended by the manufacturer. The results correlate with the number of metabolically active cells.
Beyer/Vandersee/Cosagarea/Touba/ Möbs/Assaf 
Fig. 1. Effects of $\mathrm{AsO}_{3}$ on CTCL cells. Values represent means $\pm \mathrm{SD}$. a Cell lines Hut78 (squares) and SeAx (circles) were treated for $24 \mathrm{~h}$ with $\mathrm{AsO}_{3}$ or solvent control (indicated at $0 \mu \mathrm{M}$ ) and analyzed subsequently by flow cytometry for the percentage of cells in the subG $\mathrm{G}_{1}$ fraction to determine induction of apoptosis $\left(\mathrm{n}=3,{ }^{*} \mathrm{p}<\right.$ $\left.0.05,{ }^{* *} \mathrm{p}<0.001\right)$. b Hut-78 cell culture supernatants were analyzed for LDH content by ELISA to determine cytotoxicity $\left(\mathrm{n}=3{ }^{*} \mathrm{p}<0.001\right)$. c, $\mathbf{d}$ The effect of vitamin $\mathrm{C}$ (vit. C) and N-acetylcysteine (NAC) on apoptosis induction by 2.5 and $5 \mu \mathrm{M}$ $\mathrm{AsO}_{3}$, respectively, in Hut-78 cells was analyzed by flow cytometry as described $(\mathrm{n}=3, * \mathrm{p}<0.01)$.
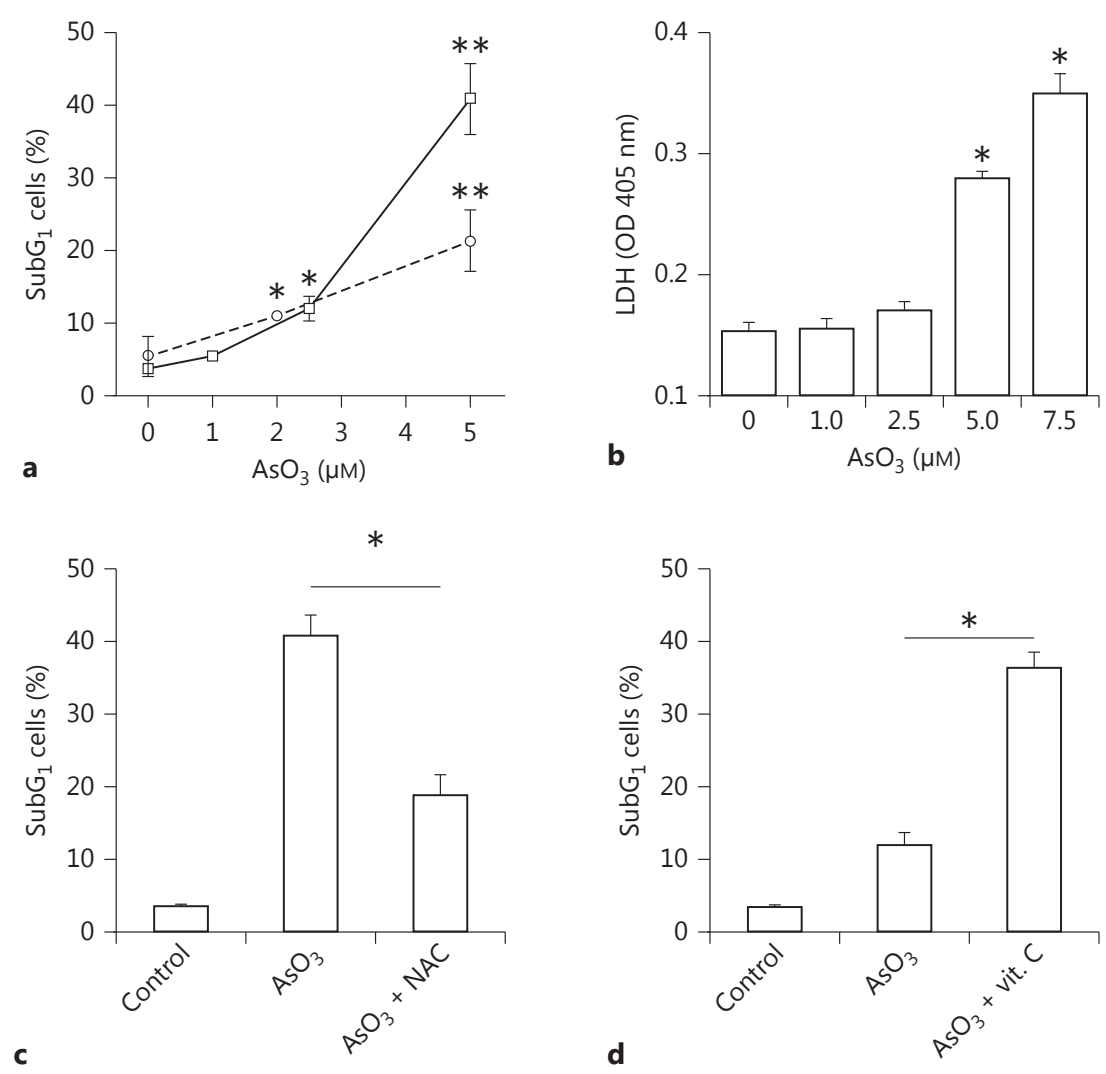

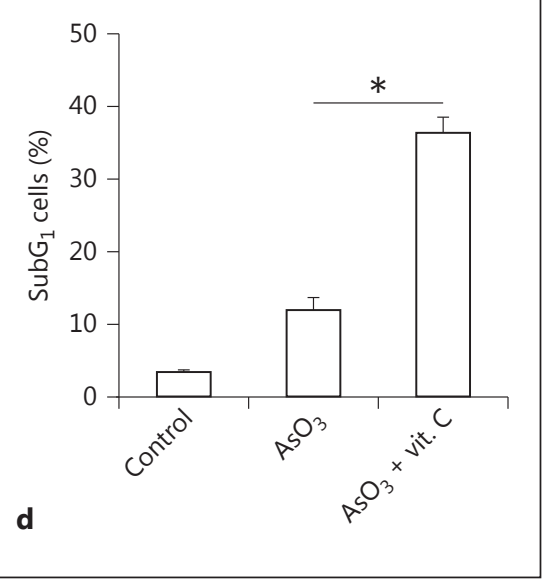

\section{Statistics}

Statistics were done using Graph Pad Prism 5 (GraphPad Software Inc., La Jolla, Calif., USA); statistical analyses were done by t test or one-way ANOVA where appropriate. Significance levels are given in the text or the figure legends.

\section{Results}

\section{Effects of $\mathrm{AsO}_{3}$ on CTCL Cells}

First we tested the effect of $\mathrm{AsO}_{3}$ on apoptosis induction in CTCL cells. To this end, the CTCL cell lines Hut78 and SeAx were incubated with different concentrations of $\mathrm{AsO}_{3}$ for $24 \mathrm{~h}$, and the rate of apoptotic cells was determined by flow-cytometric analysis (FACS) of the subG $G_{1}$ population. In both cell lines, the percentage of apoptotic cells increased concentration dependently, becoming significantly different from the control at $2.5 \mu \mathrm{M}$ for Hut-78 and at $5 \mu \mathrm{M}$ for SeAx cells (fig. 1a). To test for cytotoxic effects of $\mathrm{AsO}_{3}$ on CTCL cells, we conducted an assay analyzing the release of $\mathrm{LDH}$ as a parameter for damaged cells. Hut-78 cells were incubated as described above, and LDH content in the cell culture supernatant was measured at $24 \mathrm{~h}$. The amount of LDH was significantly increased at a concentration of $5 \mu \mathrm{M}$ (fig. 1b).

The efficacy of $\mathrm{AsO}_{3}$ for inducing apoptosis depends on the antioxidative potential of cells. Prior studies have shown that apoptosis induction by $\mathrm{AsO}_{3}$ occurs via modulation of the antioxidant glutathione [26]. Furthermore, it has been demonstrated that induction of apoptosis is increased by depletion of intracellular glutathione with ascorbic acid (vitamin C) in cancer cells including lymphoma cell lines $[19,27]$ but inhibited by $\mathrm{N}$-acetylcysteine, which increases intracellular glutathione levels in carcinoma and myeloma cells $[28,29]$.

To test if these mechanisms apply to Hut-78 and SeAx cells, both cell lines were incubated with either $1 \mathrm{~mm} \mathrm{~N}$ acetylcysteine or $100 \mu \mathrm{M}$ vitamin $\mathrm{C}$ for $1 \mathrm{~h}$ before addition of either $2.5 \mu \mathrm{M} \mathrm{AsO}_{3}$ to vitamin $\mathrm{C}$ or $5 \mu \mathrm{M} \mathrm{AsO}$ to $\mathrm{N}$ acetylcysteine for $24 \mathrm{~h}$. Apoptosis induction was measured by determination of the subG $\mathrm{G}_{1}$ population by flow cytometry as well as DNA fragmentation by ELISA. Incu- 


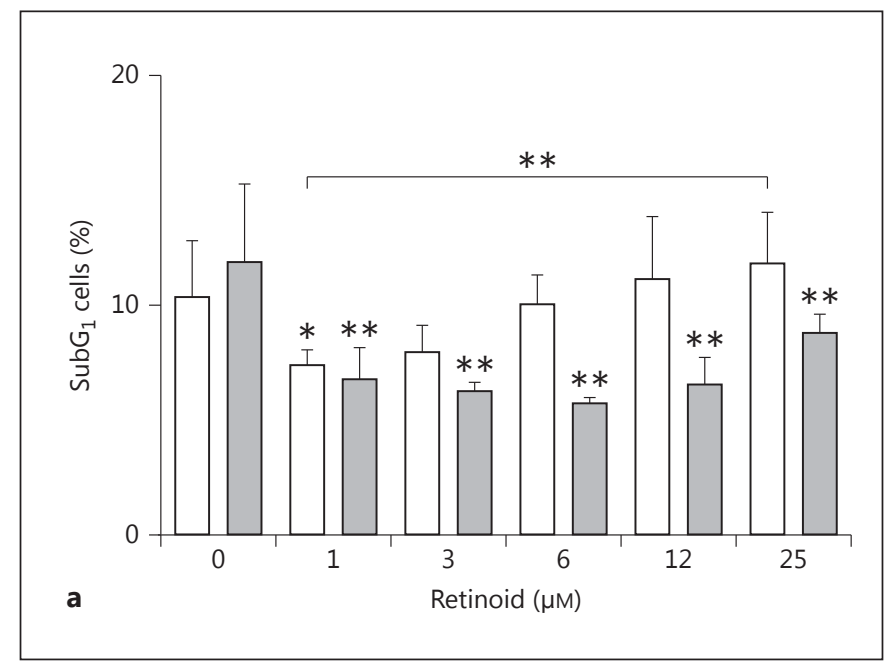

Fig. 2. Effects of retinoids on CTCL cells. Values represent means $(\mathrm{n}=9) \pm$ SD. a Hut-78 cells were treated for $72 \mathrm{~h}$ with ATRA, bexarotene or solvent control (indicated at $0 \mu \mathrm{M}$ ) and analyzed subsequently by flow cytometry for the percentage of cells in the subG fraction to determine induction of apoptosis $\left({ }^{*} \mathrm{p}<0.05,{ }^{* *} \mathrm{p}<\right.$

bation of cells with vitamin $\mathrm{C}$ or $\mathrm{N}$-acetylcysteine as a control did not induce apoptosis at the respective concentrations. While vitamin $\mathrm{C}$ led to a 3 -fold increase, $\mathrm{N}$-acetylcysteine led to a 2.2 -fold decrease in $\mathrm{AsO}_{3}$-induced apoptosis in Hut-78 cells (fig. 1c, d). These effects were also seen in the DNA fragmentation ELISA and observed after treatment of SeAx cells (data not shown). Due to the demonstration of induction of apoptosis without concomitant cytotoxic effects, we used $2.5 \mu \mathrm{M} \mathrm{AsO}_{3}$ for further experiments. The induction of apoptosis at this dose was also confirmed by demonstration of a significant increase in DNA fragmentation in Hut-78 cells after treatment with $2.5 \mu \mathrm{M} \mathrm{AsO}_{3}$ for $24 \mathrm{~h}$. It is noteworthy that the dose of $2.5 \mu \mathrm{M} \mathrm{AsO} \mathrm{O}_{3}$ has been shown to be readily achievable in patients during treatment [30].

\section{Effects of the Retinoids ATRA and Bexarotene on}

CTCL Cells Alone and in Combination with $\mathrm{AsO}_{3}$

The main scope of our study was to test whether retinoids are able to augment $\mathrm{AsO}_{3}$-induced effects in CTCL cells as it is seen in APL. For these experiments ATRA, which ligates the RAR and is used as combination partner in APL, and bexarotene, an RXR-specific retinoid approved for the treatment of primary CTCL, were used. Hut- 78 cells were incubated for $72 \mathrm{~h}$, as this time span was used in previous studies, with $1,3,6,10$, and $25 \mu \mathrm{M}$ of ATRA or bexarotene [31]. It has to be noted in this re-

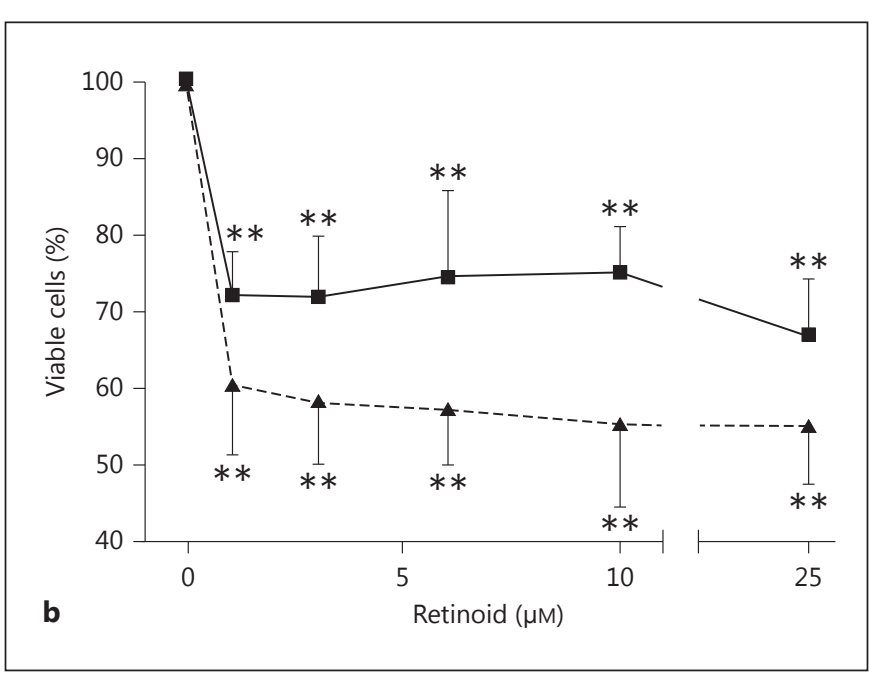

0.01). White bars represent ATRA, gray bars represent bexarotene. b Cell viability after retinoid treatment was analyzed with the WST reagent and photometry $\left({ }^{* *} \mathrm{p}<0.01\right)$; triangles represent ATRA, squares represent bexarotene.

spect that at the dosages approved for clinical use ATRA and bexarotene readily reach a plasma concentration of about 1 and $3 \mu \mathrm{M}$, respectively, as could be shown in pharmacokinetic studies [32, 33].

To determine the induction of apoptosis by retinoids, the percentage of cells in the subG $\mathrm{G}_{1}$ populations was measured by flow cytometry. Surprisingly, a significant reduction was seen after treatment with $1 \mu \mathrm{M}$ ATRA and all concentrations tested for bexarotene (fig. 2a). For ATRA a dose-dependent increase in apoptosis induction with a significant difference between 1 and $25 \mu \mathrm{M}$ was seen.

To assess cell viability, we conducted a WST assay, which correlates with the number of metabolically active cells. Despite low levels of apoptosis, a significant reduction of cell viability was seen at the concentration of $1 \mu \mathrm{M}$ ATRA or bexarotene, which was not increased dose dependently up to $25 \mu \mathrm{M}$ (fig. 2b). To exclude a cytotoxic effect of the retinoids on CTCL cells, an LDH assay was made and did not demonstrate significant differences in comparison to control treatment (data not shown).

As clear dose-dependent effects were not demonstrated for both retinoids, we chose to evaluate the effects in combination with $\mathrm{AsO}_{3}$ at the minimal and maximal dose of 1 and $25 \mu \mathrm{M}$.

Cells were first incubated for $48 \mathrm{~h}$ with the retinoid alone and then for another $24 \mathrm{~h}$ with the retinoid in combination with $2.5 \mu \mathrm{M} \mathrm{AsO}_{3}$. Analysis of the subG $\mathrm{G}_{1}$ fraction
Beyer/Vandersee/Cosagarea/Touba/ Möbs/Assaf 


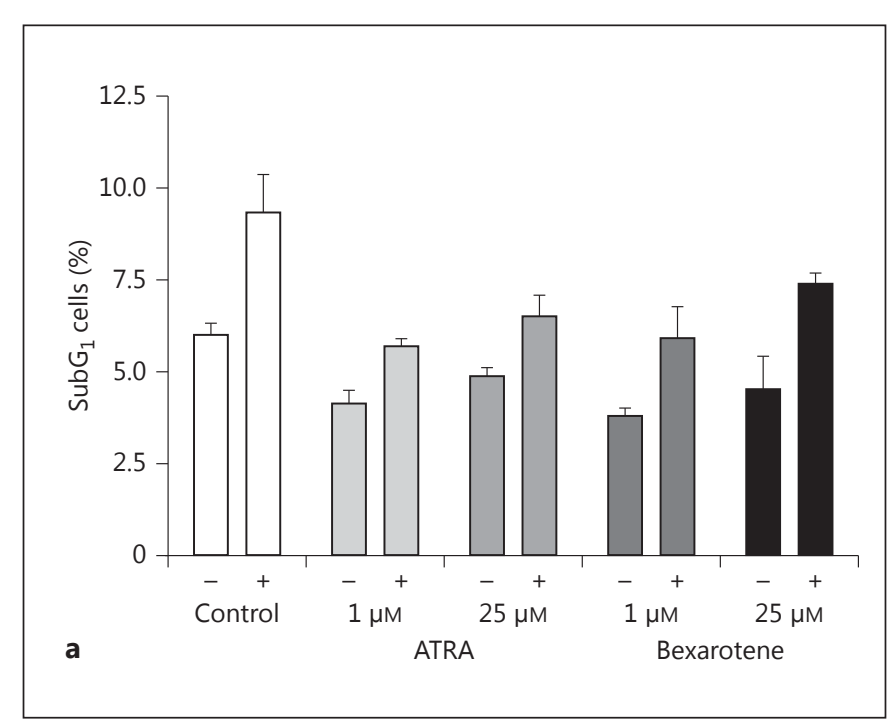

Fig. 3. Effects of combination with $\mathrm{AsO}_{3}$ and retinoids on CTCL cells. Hut-78 cells were treated for $72 \mathrm{~h}$ with ATRA, bexarotene or solvent control. $\mathrm{AsO}_{3}$ was added in indicated (+) samples at $2.5 \mu \mathrm{M}$ for the last $24 \mathrm{~h}$ of the incubation period. Cells were subsequently analyzed by flow cytometry for the percentage of cells in the subG $\mathrm{G}_{1}$ fraction to determine induction of apoptosis (a) or with the WST reagent and photometry to determine cell viability $(\mathbf{b})$. Significant differences are described in the Results section. Bars show means $(n=3) \pm$ SD. c Distribution of cells in the $G_{0 / 1}(\boldsymbol{\square}), S($ 目 $)$ and $G_{2}$ phases $(\square)$ was analyzed by FACS. Columns represent mean values from triplicates.

demonstrated that the percentage of apoptotic cells after combination treatment was significantly higher compared to ATRA but significantly lower in comparison to $\mathrm{AsO}_{3}$ alone. However, the overall effects observed were rather small. Comparable results were seen with the combination of bexarotene and $\mathrm{AsO}_{3}$, though no significant reduction of $\mathrm{AsO}_{3}$-induced apoptosis was seen at the dose of $25 \mu \mathrm{M}$ (fig. 3a).

The WST assay showed that in all settings, treatment led to a decreased cell viability compared to the control. While addition of retinoids to $\mathrm{AsO}_{3}$ resulted in a significant decrease $(\mathrm{p}<0.01)$ compared to the $\mathrm{AsO}_{3}$ alone, the combination did not further increase retinoid-induced reductions of cell viability (fig. 3b). The LDH activity in the cell culture supernatant was measured, and none of the combinations exhibited significant cytotoxic effects (data not shown). Regarding the distribution of cells in the different phases of the cell cycle, we observed only a slight reduction in cells in the $S$ phase after ATRA but not

Arsenic Trioxide and Retinoids in CTCL
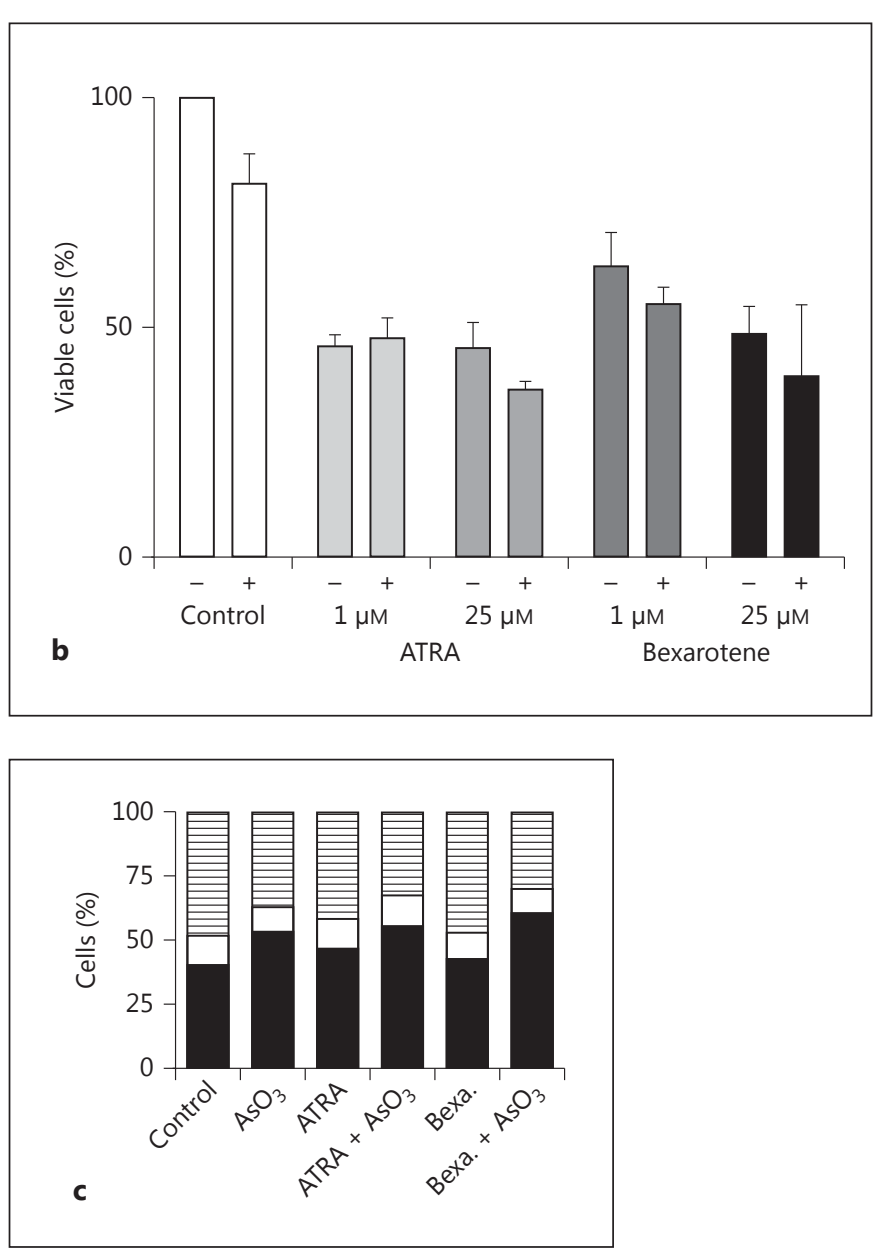

bexarotene treatment while an arrest in the $\mathrm{G}_{1}$ phase was observed for $\mathrm{AsO}_{3}$, which was not influenced by preceding retinoid treatment (fig. 3c).

\section{Discussion}

Induction of apoptosis and cell cycle arrest are thought to be major mechanisms of treatment modalities used for the treatment of CTCL like retinoids, interferons and photochemotherapy [34-36]. Previous data on the successful use of $\mathrm{AsO}_{3}$ in conjunction with the retinoid ATRA in APL led us to the question whether this combination might also prove beneficial in the therapy of CTCL. In APL a distinct mutation resulting in a fusion gene of the RAR- $\alpha$ and tumor-propagating genes are thought to represent the target for ATRA. Although such a driving mutation has not been demonstrated in CTCL, both ATRA and bexarotene have been reported to be efficient 
in CTCL treatment and to affect the microenvironment of the tumor cells, e.g. protein expression in keratinocytes [37-41]. Our results demonstrate that incubation of CTCL cell lines with $\mathrm{AsO}_{3}$ leads to a dose-dependent increase in apoptosis without cytotoxic side effects at concentrations that can be reached under therapeutical conditions. Only at higher concentrations like $5 \mu \mathrm{M}$ was LDH significantly increased arguing for a direct cytotoxic effect of $\mathrm{AsO}_{3}$ at this concentration. Additionally, we confirmed the augmenting effects of vitamin $\mathrm{C}$ on apoptosis induction and introduce data that $\mathrm{N}$-acetylcysteine also in CTCL cell lines almost completely countermands the effects of $\mathrm{AsO}_{3}$ underlining the importance of the cell's redox system for both the apoptotic effect of $\mathrm{AsO}_{3}$ and carcinogenesis in CTCL or in general $[42,43]$. Furthermore, the concentration of vitamin $\mathrm{C}$ used is nearly reached in the plasma under normal nutritional conditions, leading to the question whether a dietarily induced higher uptake could influence the efficacy of treatment [44].

When investigating the effects of retinoids alone, we found a significant increase in apoptosis neither for ATRA nor for bexarotene after $72 \mathrm{~h}$ of treatment. This time span has been sufficient in some but not in other reports on apoptosis induction of retinoids in CTCL cells. As different working groups have employed varying analytic settings regarding dose range, incubation periods and cell type, the results obtained are not easily comparable. In our experiments neither RAR- nor RXR-specific retinoids induced significant apoptosis but reduced cell viability in CTCL cells after treatment for $72 \mathrm{~h}$. These observations argue for an antiproliferative effect preceding apoptosis induction as the reduction in cell number was not explained by direct cytotoxic effects. This is in line with a paper pointing towards a proliferative arrest at different cell cycle stages by bexarotene [20,22]. Furthermore, induction of apoptosis in vivo could not be demonstrated. Finally, other modes of action such as reduction of T-cell migration, e.g. via expression of homing receptors expressed by the tumor cells, may also play a role in bexarotene-induced responses seen in CTCL patients $[45,46]$. In conclusion, in our experiments retinoids did not induce significant alterations of the cell cycle as it has been described before for bexarotene. In contrast to a strong $\mathrm{G}_{1}$ arrest in adult $\mathrm{T}$-cell leukemia cells by $\mathrm{AsO}_{3}$ treatment, incubation of CTCL cells with $\mathrm{AsO}_{3}$ led to only a slight increase in the $\mathrm{G}_{1 / 0}$ fraction $[47,48]$.

In combination with $\mathrm{AsO}_{3}$ both retinoids reduced apoptosis induction by $\mathrm{AsO}_{3}$ significantly, whereas reduction in cell viability was unaltered in all combinations

applied. Therefore, our experiments did not demonstrate an additive or synergistic effect with regard to induction of apoptosis or reduction of cell viability. Furthermore, we did not observe cytotoxic effects of the combination treatment in vitro at pharmacologically tolerated doses, which correlates with the tolerability of combined ATRA and $\mathrm{AsO}_{3}$ treatment of APL patients. In the literature, $\mathrm{AsO}_{3}$ has so far only been used in 2 patients with Sézary syndrome or erythrodermic mycosis fungoides, resulting in stable disease and partial remission, respectively. These remissions, though, were reported to last for only a week after discontinuation of therapy because of adverse events [19]. These results suggest the necessity of a combination partner other than retinoids, should $\mathrm{AsO}_{3}$ play a future role in CTCL treatment. In adult T-cell leukemia, several studies report on the successful combination of $\mathrm{AsO}_{3}$ with interferon- $\alpha[49,50]$. As the latter represents another important substance for CTCL therapy, this might be an interesting combination for future studies.

\section{Acknowledgment}

The study has been financed in part by a research grant from TEVA.

\section{Disclosure Statement}

Chalid Assaf received honoraria for advisory board meetings and presentations from TEVA and Cephalon oncology. Marc Beyer received research grants and honoraria for a presentation from Cephalon oncology and for an advisory board meeting from TEVA. Ioana Cosagarea received a travel grant from TEVA.

References

Skin Pharmacol Physiol 2016;29:63-70 DOI: $10.1159 / 000443840$
Beyer/Vandersee/Cosagarea/Touba/ Möbs/Assaf
1 Agar NS, Wedgeworth E, Crichton S, Mitchell TJ, Cox M, Ferreira S, et al: Survival outcomes and prognostic factors in mycosis fungoides/ Sézary syndrome: validation of the revised International Society for Cutaneous Lymphomas/European Organisation for Research and Treatment of Cancer staging proposal. J Clin Oncol 2010;28:4730-4739.

2 Willemze R, Jaffe ES, Burg G, Cerroni L, Berti E, Swerdlow SH, et al: WHO-EORTC classification for cutaneous lymphomas. Blood 2005; 105:3768-3785.

3 Imam MH, Shenoy PJ, Flowers CR, Phillips A, Lechowicz MJ: Incidence and survival patterns of cutaneous T-cell lymphomas in the United States. Leuk Lymphoma 2013;54:752759.
68 
4 Meech SJ, Edelson R, Walsh P, Norris DA, Duke RC: Reversible resistance to apoptosis in cutaneous T cell lymphoma. Ann NY Acad Sci 2001;941:46-58.

5 Nevala H, Karenko L, Vakeva L, Ranki A: Proapoptotic and antiapoptotic markers in cutaneous T-cell lymphoma skin infiltrates and lymphomatoid papulosis. Br J Dermatol 2001; 145:928-937.

6 Kiessling MK, Klemke CD, Kaminski MM, Galani IE, Krammer PH, Gülow K: Inhibition of constitutively activated nuclear factor-kap$\mathrm{paB}$ induces reactive oxygen species- and iron-dependent cell death in cutaneous T-cell lymphoma. Cancer Res 2009;69:2365-2374.

7 Al-Yacoub N, Fecker LF, Möbs M, Plötz M, Braun FK, Sterry W, Eberle J: Apoptosis induction by SAHA in cutaneous T-cell lymphoma cells is related to downregulation of c-FLIP and enhanced TRAIL signaling. J Invest Dermatol 2012;132:2263-2274.

8 Stadler R, Assaf C, Klemke CD, Nashan D, Weichenthal M, Dummer R, Sterry W: Brief S2k guidelines - cutaneous lymphomas. J Dtsch Dermatol Ges 2013;11(suppl 3):19-28.

9 Farkas A, Kemeny L, French LE, Dummer R: New and experimental skin-directed therapies for cutaneous lymphomas. Skin Pharmacol Physiol 2009;22:322-334.

10 Hughes CF, Khot A, McCormack C, Lade S, Westerman DA, Twigger R, Buelens O, Newland K, Tam C, Dickinson M, Ryan G, Ritchie D, Wood C, Prince HM: Lack of durable disease control with chemotherapy for mycosis fungoides and Sézary syndrome: a comparative study of systemic therapy. Blood 2015; 125:71-81.

11 Kaye FJ, Bunn PA Jr, Steinberg SM, Stocker JL, Ihde DC, Fischmann AB, Glatstein EJ, Schechter GP, Phelps RM, Foss FM, et al: A randomized trial comparing combination electron-beam radiation and chemotherapy with topical therapy in the initial treatment of mycosis fungoides. N Engl J Med 1989;321: 1784-1790.

12 Antman KH: Introduction: the history of arsenic trioxide in cancer therapy. Oncologist 2001;6(suppl 2):1-2.

13 Douer D, Tallman MS: Arsenic trioxide: new clinical experience with an old medication in hematologic malignancies. J Clin Oncol 2005; 23:2396-2410.

14 Zhang XY, Yang SM, Zhang HP, Yang Y, Sun SB, Chang JP, Tao XC, Yang TY, Liu C, Yang YM: Endoplasmic reticulum stress mediates the arsenic trioxide-induced apoptosis in human hepatocellular carcinoma cells. Int J Biochem Cell Biol 2015;68:158-165.

15 Jiao G, Ren T, Guo W, Ren C, Yang K: Arsenic trioxide inhibits growth of human chondrosarcoma cells through $\mathrm{G}_{2} / \mathrm{M}$ arrest and apoptosis as well as autophagy. Tumour Biol 2015; 36:3969-3977.

16 Huang XC, Maimaiti XY, Huang CW, Zhang L, Li ZB, Chen ZG, Gao X, Chen TY: Synergistic effects of arsenic trioxide combined with ascorbic acid in human osteosarcoma
MG-63 cells: a systems biology analysis. Eur Rev Med Pharmacol Sci 2014;18:3877-3888.

17 Chen G-Q, Zhu J, Shi X-G, et al: In vitro studies on cellular and molecular mechanisms of arsenic trioxide $\left(\mathrm{As}_{2} \mathrm{O}_{3}\right)$ in the treatment of acute promyelocytic leukemia: $\mathrm{As}_{2} \mathrm{O}_{3}$ induces NB4 cell apoptosis with downregulation of Bcl-2 expression and modulation of PMLRARa/PML proteins. Blood 1996;88:10521061.

18 Soignet SL, Maslak P, Wang ZG, Jhanwar S, Calleja E, Dardashti LJ, Corso D, DeBlasio A, Gabrilove J, Scheinberg DA, Pandolfi PP, Warrell RP Jr: Complete remission after treatment of acute promyelocytic leukemia with arsenic trioxide. N Engl J Med 1998;339: 1341-1348.

19 Michel L, Dupuy A, Jean-Louis F, Sors A, Poupon J, Viguier M, Musette P, Dubertret L, Degos L, Dombret H, Bachelez H: Arsenic trioxide induces apoptosis of cutaneous $\mathrm{T}$ cell lymphoma cells: evidence for a partially caspase-independent pathway and potentiation by ascorbic acid (vitamin C). J Invest Dermatol 2003;121:881-893.

20 Tun-Kyi A, Qin JZ, Oberholzer PA, Navarini AA, Hassel JC, Dummer R, Döbbeling U: Arsenic trioxide down-regulates antiapoptotic genes and induces cell death in mycosis fungoides tumors in a mouse model. Ann Oncol 2008;19:1488-1494.

21 Berbis P: Retinoids: mechanisms of action. Ann Dermatol Venereol 2010;137(suppl 3):97-103.

22 Nieto-Rementería N, Pérez-Yarza G, Boyano MD, Apraiz A, Izu R, Díaz-Pérez JL, Asumendi A: Bexarotene activates the p53/p73 pathway in human cutaneous T-cell lymphoma. Br J Dermatol 2009;160:519-526.

23 Amann PM, Czaja K, Bazhin AV, Rühl R, Eichmüller SB, Merk HF, Baron JM: LRAT overexpression diminishes intracellular levels of biologically active retinoids and reduces retinoid antitumor efficacy in the murine melanoma B16F10 cell line. Skin Pharmacol Physiol 2015;28:205-212.

24 Kaltoft K, Bisballe S, Rasmussen HF, Thestrup-Pedersen K, Thomsen K, Sterry W: A continuous $\mathrm{T}$-cell line from a patient with Sézary syndrome. Arch Dermatol Res 1987; 279:293-298.

25 Gootenberg JE, Ruscetti FW, Mier JW, Gazdar A, Gallo RC: Human cutaneous T cell lymphoma and leukemia cell lines produce and respond to $\mathrm{T}$ cell growth factor. J Exp Med 1981;154:1403-1418.

26 Dai J, Weinberg RS, Waxman S, Jing Y: Malignant cells can be sensitized to undergo growth inhibition and apoptosis by arsenic trioxide through modulation of the glutathione redox system. Blood 1999;93:268-277.

27 Akao Y, Yamada H, Nakagawa Y: Arsenicinduced apoptosis in malignant cells in vitro. Leuk Lymphoma 2000;37:53-63.

28 McCafferty-Grad J, Bahlis NJ, Krett N, Agui$\operatorname{lar}$ TM, Reis I, Lee KP, Boise LH: Arsenic trioxide uses caspase-dependent and caspase- independent death pathways in myeloma cells. Mol Cancer Ther 2003;2:1155-1164.

29 Han YH, Kim SZ, Kim SH, Park WH: Suppression of arsenic trioxide-induced apoptosis in HeLa cells by $\mathrm{N}$-acetylcysteine. Mol Cells 2008;26:18-25.

30 Shen ZX, Chen GQ, Ni JH, Li XS, Xiong SM, Qiu QY, Zhu J, Tang W, Sun GL, Yang KQ, Chen Y, Zhou L, Fang ZW, Wang YT, Ma J, Zhang P, Zhang TD, Chen SJ, Chen Z, Wang $\mathrm{ZY}$ : Use of arsenic trioxide $\left(\mathrm{As}_{2} \mathrm{O}_{3}\right)$ in the treatment of acute promyelocytic leukemia (APL). II. Clinical efficacy and pharmacokinetics in relapsed patients. Blood 1997;89:3354-3360.

31 Budgin JB, Richardson SK, Newton SB, Wysocka M, Zaki MH, Benoit B, Rook AH: Biological effects of bexarotene in cutaneous T-cell lymphoma. Arch Dermatol 2005; 141: 315-321.

32 Adamson PC, Bailey J, Pluda J, Poplack DG, Bauza S, Murphy RF, Yarchoan R, Balis FM: Pharmacokinetics of all-trans-retinoic acid administered on an intermittent schedule. J Clin Oncol 1995; 13:1238-1241.

33 Miller VA, Benedetti FM, Rigas JR, Verret AL, Pfister DG, Straus D, Kris MG, Crisp M, Heyman R, Loewen GR, Truglia JA, Warrell RP Jr: Initial clinical trial of a selective retinoid $\mathrm{X}$ receptor ligand, LGD1069. J Clin Oncol 1997; 15:790-795.

34 Zhang C, Hazarika P, Ni X, Weidner DA, Duvic $\mathrm{M}$ : Induction of apoptosis by bexarotene in cutaneous T-cell lymphoma cells: relevance to mechanism of therapeutic action. Clin Cancer Res 2002;8:1234-1240.

35 Kanetaka Y, Hayashida M, Hoshika A, Yanase $\mathrm{N}$, Mizuguchi J: Interferon-alpha induces transient upregulation of c-FLIP through NFkappaB activation. Exp Cell Res 2008;314: 246-254.

36 Yoo EK, Rook AH, Elenitsas R, Gasparro FP, Vowels BR: Apoptosis induction of ultraviolet light $\mathrm{A}$ and photochemotherapy in cutaneous T-cell lymphoma: relevance to mechanism of therapeutic action. J Invest Dermatol 1996;107:235-242.

37 Querfeld C, Rosen ST, Guitart J, Rademaker A, Fung BB, Posten W, Kuzel TM: Comparison of selective retinoic acid receptor- and retinoic X receptor-mediated efficacy, tolerance, and survival in cutaneous T-cell lymphoma. J Am Acad Dermatol 2004;51:25-32.

$38 \mathrm{Ma} \mathrm{H}$, Yang J: Insights into the all-trans-retinoic acid and arsenic trioxide combination treatment for acute promyelocytic leukemia: a meta-analysis. Acta Haematol 2015;134: 101-108.

39 Telgenhoff D, Ramsay S, Hilz S, Slusarewicz P, Shroot B: Claudin 2 mRNA and protein are present in human keratinocytes and may be regulated by all-trans-retinoic acid. Skin Pharmacol Physiol 2008;21:211-217.

40 Bi X, Gu J, Guo Z, Tao S, Wang Y, Tang L, Wu J, Mi Q: Different pathways are involved in arsenic-trioxide-induced cell proliferation and growth inhibition in human keratinocytes. Skin Pharmacol Physiol 2010;23:68-78. 
41 Duvic M, Hymes K, Heald P, Breneman D, Martin AG, Myskowski P, Crowley C, Yocum RC; Bexarotene Worldwide Study Group: Bexarotene is effective and safe for treatment of refractory advanced-stage cutaneous T-cell lymphoma: multinational phase II-III trial results. J Clin Oncol 2001; 19:2456-2471.

42 Kiessling MK, Klemke CD, Kaminski MM, Galani IE, Krammer PH, Gülow K: Inhibition of constitutively activated nuclear factor-kappaB induces reactive oxygen speciesand iron-dependent cell death in cutaneous T-cell lymphoma. Cancer Res 2009;69: 2365-2374.

43 Wölfle U, Seelinger G, Bauer G, Meinke MC, Lademann J, Schempp CM: Reactive molecule species and antioxidative mechanisms in normal skin and skin aging. Skin Pharmacol Physiol 2014;27:316-332.
44 Finglas PM, Bailey A, Walker A, Loughridge JM, Wright AJ, Southon S: Vitamin C intake and plasma ascorbic acid concentration in adolescents. Br J Nutr 1993;69:563-576.

45 Richardson SK, Newton SB, Bach TL, Budgin JB, Benoit BM, Lin JH, Yoon JS, Wysocka M, Abrams CS, Rook AH: Bexarotene blunts malignant T-cell chemotaxis in Sezary syndrome: reduction of chemokine receptor 4-positive lymphocytes and decreased chemotaxis to thymus and activation-regulated chemokine. Am J Hematol 2007;82:792-797.

46 Wang L, DeMarco SS, Chen J, Phillips CM, Bridges LC: Retinoids bias integrin expression and function in cutaneous T-cell lymphoma. J Invest Dermatol 2015;135:21022108.

47 Ishitsuka K, Kitazono M, Hanada S, Suzuki S, Utsunomiya A, Takeshita T, Uozumi K, Akiyama S, Arima T: Arsenic trioxide induces apoptosis and cell cycle arrest at $\mathrm{G}_{1}$ phase to HTLV-1 infected T-cell lines with modulation of bak and Kipl/p27 expression. Blood 1998;92(suppl 1):245a.

48 Ishitsuka K, Hanada S, Uozumi K, Utsunomiya A, Arima T: Arsenic trioxide and the growth of human T-cell leukemia virus type I infected T-cell lines. Leuk Lymphoma 2000; 37:649-655.

49 Haidar JH, Hermine O, de Thé H: Arsenic trioxide and interferon-alpha synergize to induce cell cycle arrest and apoptosis in human T-cell lymphotropic virus type I-transformed cells. Blood 1999;93:278-283.

50 Ishitsuka K, Suzumiya J, Aoki M, Ogata K, Hara S, Tamura K: Therapeutic potential of arsenic trioxide with or without interferonalpha for relapsed/refractory adult T-cell leukemia/lymphoma. Haematologica 2007;92: 719-720. 